\title{
Postsynaptic Action of Brain-Derived Neurotrophic Factor Attenuates $\alpha 7$ Nicotinic Acetylcholine Receptor-Mediated Responses in Hippocampal Interneurons
}

\author{
Catarina C. Fernandes, ${ }^{\star}$ António Pinto-Duarte, ${ }^{\star}$ Joaquim Alexandre Ribeiro, and Ana M. Sebastião \\ Institute of Pharmacology and Neurosciences, Faculty of Medicine and Unit of Neurosciences, Institute of Molecular Medicine, University of Lisbon, 1649- \\ 028 Lisbon, Portugal
}

\begin{abstract}
Nicotinic mechanisms acting on the hippocampus influence attention, learning, and memory and constitute a significant therapeutic target for many neurodegenerative, neurological, and psychiatric disorders. Here, we report that brain-derived neurotrophic factor (BDNF) (1-100 ng/ml), a member of the neurotrophin gene family, rapidly decreases $\alpha 7$ nicotinic acetylcholine receptor responses in interneurons of the hippocampal CA1 stratum radiatum. Such effect is dependent on the activation of the TrkB receptor and involves the actin cytoskeleton; noteworthy, it is compromised when the extracellular levels of the endogenous neuromodulator adenosine are reduced with adenosine deaminase $(1 \mathrm{U} / \mathrm{ml})$ or when adenosine $\mathrm{A}_{2 \mathrm{~A}}$ receptors are blocked with SCH 58261 (2-(2-furanyl)-7-(2phenylethyl)-7H-pyrazolo[4,3-e][1,2,4] triazolo[1,5-c]pyrimidin-5-amine) (100 nм). The intracellular application of U73122 (1[6[[(17 $\beta)$-3-methoxyestra-1,3,5(10)-trien-17-yl]amino]hexyl]-1H-pyrrole-2,5-dione) $(5 \mu \mathrm{M})$, a broad-spectrum inhibitor of phospholipase C, or GF 109203X (bisindolylmaleimide I) $(2 \mu \mathrm{M})$, a general inhibitor of protein kinase C isoforms, blocks BDNF-induced inhibition of $\alpha 7$ nicotinic acetylcholine receptor function. Moreover, in conditions of simultaneous intracellular dialysis of the fast $\mathrm{Ca}^{2+} \mathrm{chelator}$ BAPTA $(10 \mathrm{~mm})$ and removal of extracellular $\mathrm{Ca}^{2+}$ ions, the inhibitory action of BDNF is further prevented. The present findings disclose a novel target for rapid actions of BDNF that might play important roles on synaptic transmission and plasticity in the brain.
\end{abstract}

Key words: brain-derived neurotrophic factor; TrkB receptor; nicotinic acetylcholine receptor; protein kinases; interneurons; hippocampus

\section{Introduction}

Neuronal nicotinic acetylcholine receptors (nAChRs) are widely expressed in the brain and have been implicated in a variety of behaviors and neuropathologies. The homopentameric $\alpha 7$ subtype of $\mathrm{nAChR}$, in particular, has determinant actions in the hippocampus by supplying calcium signals that depolarize cells and influence several calcium-dependent events, including transmitter release and plasticity (Gray et al., 1996; Alkondon et al., 1997; Radcliffe and Dani, 1998; Ji et al., 2001). In agreement, it has been suggested that the decline, disruption, or alterations of $\alpha 7$ $\mathrm{nAChR}$ function might be involved in Alzheimer's disease (Guan et al., 2000; Wang et al., 2000), in auditory gating deficits associated with schizophrenia (Freedman et al., 1994), and in juvenile myoclonic epilepsy (Elmslie et al., 1997). Because of the high relative permeability of $\alpha 7 \mathrm{nAChRs}$ to calcium, which inclusively

Received Dec. 5, 2007; revised March 17, 2008; accepted April 17, 2008.

This work was supported by a grant from the Portuguese Foundation for Science and Technology (FCT) and by a European Union concerted action. C.C.F. and A.P.-D. were supported by FCT PhD Grants SFRH/BD/18046/2004 and SFRH/BD/21589/2005. We thank Drs. Gunnar Gouras, Tiago Fleming Outeiro, and Lori Wetmore for comments on a previous version of this manuscript. The gift of BDNF from Regeneron Pharmaceuticals is also acknowledged.

${ }^{*}$ C.C.F. and A.P.-D. contributed equally to this work.

The authors declare no competing financial interests.

Correspondence should be addressed to Catarina C. Fernandes, Avenida Prof. Egas Moniz, Edifício Egas Moniz, Piso B1, 1649-028 Lisbon, Portugal. E-mail: cfernandes@fm.ul.pt.

DOI:10.1523/JNEUROSCI.5378-07.2008

Copyright $\odot 2008$ Society for Neuroscience $\quad$ 0270-6474/08/285611-08\$15.00/0 exceeds that of NMDA receptors (Bertrand et al., 1993; Seguela et al., 1993), $\alpha 7$ nAChR-mediated responses must be precisely controlled and multiple signaling pathways must converge on their regulation. Recent evidences suggest a link between the neurotrophin-gene family member brain-derived neurotrophic factor (BDNF) and $\alpha 7 \mathrm{nAChRs}$ in hippocampal interneurons, in which BDNF leads to an increase in $\alpha 7 \mathrm{nAChR}$ number and clustering over a time course of several hours to days (Kawai et al., 2002; Massey et al., 2006). Despite the initial description of BDNF as a trophic molecule of the CNS with important long-term functions on neuronal survival, differentiation, and neurite outgrowth (Thoenen, 1991), this neurotrophin has emerged as an acute modulator of neuronal function (Kang and Schuman, 1995; Korte et al., 1995; Figurov et al., 1996; Patterson et al., 1996) because of the actions of downstream intracellular kinases and effector proteins triggered immediately after BDNF binding to TrkB receptors (for review, see Poo, 2001). In this regard, we hypothesized that BDNF might drive acute changes in $\alpha 7$ nAChR-mediated responses that are required for a precise and rapid modulation of synaptic properties. Our results show that BDNF, acting on the tyrosine kinase TrkB receptor, induces a rapid decrease of $\alpha 7 \mathrm{nAChR}$-mediated responses in hippocampal interneurons of the CA1 stratum radiatum. We also demonstrate that such inhibitory effect of BDNF involves the actin cytoskeleton and occurs through the activation of the phospholipase $\mathrm{C}$ 
(PLC)/protein kinase $\mathrm{C}(\mathrm{PKC})$ pathway, requiring $\mathrm{Ca}^{2+}$ ions as a cofactor.

\section{Materials and Methods}

All experiments were in accordance with European Community and National Institutes of Health guidelines for animal care and use. Animals were maintained on a $12 \mathrm{~h}$ light/dark cycle and were provided food and water ad libitum.

Chemicals. 6-Cyano-2,3-dihydroxy-7-nitro-quinoxaline (CNQX), 2-amino-5-phosphonovalerate (APV), bicuculline methochloride, tetrodotoxin citrate (TTX), 2-(2-furanyl)-7-(2-phenylethyl)-7 $\mathrm{H}$ pyrazolo[4,3-e] $[1,2,4]$ triazolo[1,5-c]pyrimidin-5-amine (SCH 58261), 1-[6[[(17 $\beta)$-3-methoxyestra-1,3,5(10)-trien-17-yl] amino]hexyl]-1 Hpyrrole-2,5-dione (U73122), 4-amino-5-(4-chlorophenyl)-7- $(t$ butyl)pyrazolo[3,4-d]pyrimidine (PP2), and bisindolylmaleimide I (GF 109203X) were from Tocris Bioscience. Acetylcholine chloride (ACh), choline chloride (Ch), methyllycaconitine citrate (MLA), dihydro- $\beta$ erythroidine hydrobromide ( $\mathrm{dh} \beta \mathrm{e})$, phorbol-12,13-didecanoate (PDD), $\mathrm{N}$-[2-( $p$-bromocinnamylamino)ethyl]-5-isoquinoline-sulfonamide $(\mathrm{H}$ 89), cytochalasin D (Cyt D), and gramicidin were from Sigma. $\alpha$-Bungarotoxin $(\alpha$-BT) and K252a were obtained from Merck Biosciences. Adenosine deaminase (ADA) was provided by Roche Applied Science in a $200 \mathrm{U} / \mathrm{ml}$ stock solution in $50 \%$ glycerol $(\mathrm{v} / \mathrm{v})$ and $10 \mathrm{~mm}$ potassium phosphate, $\mathrm{pH} \approx 6$. BDNF was kindly provided by Regeneron Pharmaceuticals in a $1.0 \mathrm{mg} / \mathrm{ml}$ stock solution in $150 \mathrm{~mm} \mathrm{NaCl}, 10 \mathrm{~mm}$ sodium phosphate buffer, and $0.004 \%$ Tween 20. Inactivated BDNF (HI$\mathrm{BDNF})$ was prepared by heating aliquots to $100^{\circ} \mathrm{C}$ for $30 \mathrm{~min}$. ACh $(0.5$ $\mathrm{M})$, Ch (0.5 M), TTX (1 mm), APV (25 mм), MLA (10 mm), $\alpha$-BT (20 $\mathrm{mm}), \mathrm{H}-89(1 \mathrm{~mm})$, and $\mathrm{dh} \beta \mathrm{e}(10 \mathrm{~mm})$ were prepared as stock solution in water. CNQX (100 mM), bicuculline (100 mM), SCH 58261 (5 mM), K252a (1 mM), PP2 (20 mм), U73122 (5 mm), GF 109203X (1 mM), PDD $(1 \mathrm{~mm})$, Cyt D (5 mM), and gramicidin $(100 \mathrm{mg} / \mathrm{ml})$ were prepared as a stock solution in DMSO. The percentage of vehicle (DMSO) in each experiment did not exceed $0.1 \%$. Stock solutions were aliquoted and stored at $-20^{\circ} \mathrm{C}$, except for BDNF, which was stored at $-80^{\circ} \mathrm{C}$, and aqueous dilutions of these stock solutions were made freshly before the experiment.

Tissue preparation. The procedures were identical to those described previously (Diogenes et al., 2004). Transverse hippocampal slices (300 $\mu \mathrm{m}$ thick) from 3- to 4-week-old male Wistar rats (Harlan Interfauna Iberica) were cut in an ice-cold solution containing the following (in mu): 110 sucrose, $2.5 \mathrm{KCl}, 0.5 \mathrm{CaCl}_{2}, 7 \mathrm{MgCl}_{2}, 25 \mathrm{NaHCO}_{3}, 1.25$ $\mathrm{NaH}_{2} \mathrm{PO}_{4}$, and 10 glucose, $\mathrm{pH} 7.4$ (bubbled with $95 \% \mathrm{O}_{2} / 5 \% \mathrm{CO}_{2}$ ). Slices were then incubated in artificial CSF containing $124 \mathrm{~mm} \mathrm{NaCl}, 3$ $\mathrm{mm} \mathrm{KCl}, 1.25 \mathrm{~mm} \mathrm{NaH}_{2} \mathrm{PO}_{4}, 26 \mathrm{~mm} \mathrm{NaHCO}_{3}, 1 \mathrm{~mm} \mathrm{MgSO}_{4}, 2 \mathrm{~mm}$ $\mathrm{CaCl}_{2}$, and $10 \mathrm{~mm}$ glucose, $\mathrm{pH} 7.4$, equilibrated with $95 \% \mathrm{O}_{2} / 5 \% \mathrm{CO}_{2}$ at $35^{\circ} \mathrm{C}$ for $30 \mathrm{~min}$ and afterward maintained at room temperature $(22$ $24^{\circ} \mathrm{C}$ ) for at least $1 \mathrm{~h}$ before use.

Electrophysiology. Whole-cell recordings were obtained from interneurons located at the CA1 stratum radiatum and at the border of the strata radiatum and lacunosum moleculare (see Fig. 1). Interneurons were visualized with an upright microscope (Zeiss Axioskop 2FS) equipped with infrared video microscopy and differential interference contrast optics. Cells were held at a membrane potential of $-70 \mathrm{mV}$, and recordings were performed at room temperature $\left(22-24^{\circ} \mathrm{C}\right)$. The internal solution consisted of the following (in $\mathrm{mM}$ ): 125 potassium gluconate, $11 \mathrm{KCl}, 0.1 \mathrm{CaCl}_{2}, 2 \mathrm{MgCl}_{2}$, 1 EGTA, 10 HEPES, $2 \mathrm{NaATP}, 0.3 \mathrm{NaGTP}$, and 10 Tris phosphocretatine, $\mathrm{pH} 7.3$ adjusted with $\mathrm{KOH}, 280-290$ mOsm. In some experiments (when indicated), K252a (200 nM), U73122 $(5 \mu \mathrm{M})$, PP2 (100 nM), or GF 109203X (2 $\mu \mathrm{M})$ dissolved in DMSO $(0.1 \%)$ were included in the internal solution; matching controls were performed with an equal percentage of DMSO in the intracellular solution. For perforated-patch recordings, gramicidin was diluted in the filling solution to a final concentration of $100 \mu \mathrm{g} / \mathrm{ml}$. The tip of the electrode was filled with gramicidin-free pipette solution. Pipettes resistances were 5-7 M $\Omega$. Series resistance was measured by the instantaneous current response to a $-1 \mathrm{mV}$ step with the pipette capacitance cancelled.

$\alpha 7 \mathrm{nAChR}$-mediated currents were evoked using a pressure ejection system (PicoPump PV820; World Precision Instruments). A patch pi- pette containing ACh (1 mM) or Ch (10 mM) was positioned near the cell bodies, and pulses of pressure were applied (single $30 \mathrm{~ms}$ puffs, $5-10 \mathrm{psi}$, applied at $3 \mathrm{~min}$ intervals). Stable baselines of $30 \mathrm{~min}$, at least, were obtained before starting each trial. Nicotinic responses were recorded using a EPC7 amplifier (List Biologic), filtered at 10 and $3 \mathrm{kHz}$ through a three-pole Bessel filter and digitized at $5 \mathrm{kHz}$ with WinLTP software (Anderson and Collingridge, 2007).

All recordings were performed in the presence of TTX (1 $\mu \mathrm{M})$, CNQX (25 $\mu \mathrm{M})$, APV $(10 \mu \mathrm{M})$, and bicuculline $(20 \mu \mathrm{M})$.

Experiments were rejected if the superfusion of hippocampal slices with the selective $\alpha 7 \mathrm{nAChR}$ antagonists MLA (10 nM) or $\alpha$-BTx (100 nM) failed to completely block $\alpha 7$ nAChR-mediated currents at the end of the trials.

Data analysis. Results are expressed as the mean \pm SEM of $n$ experiments. Statistical significance was assessed by a two-tailed Student's $t$ test for the effect of BDNF versus control (absence of drugs) and with oneway ANOVA followed by the Tukey-Kramer post hoc test for comparison between multiple groups. Analyses were conducted with the Prism version 4.00 for Windows (GraphPad Software).

\section{Results \\ BDNF induces a rapid depression of $\alpha 7$ nAChR-mediated currents}

The activity of $\alpha 7 \mathrm{nAChRs}$ was assessed through whole-cell patch-clamp experiments by applying ACh (1 mM) or Ch (10 $\mathrm{mm}$ ) onto the soma of interneurons located in the stratum radiatum and at the border of the strata radiatum/lacunosummoleculare of the CA1 hippocampal region. This procedure elicited $\alpha 7 \mathrm{nAChR}$-mediated whole-cell currents that were sensitive to $10 \mathrm{~nm}$ MLA or $100 \mathrm{~nm} \alpha$-BTx (Fig. 1). To avoid potential contaminating effects, fast glutamatergic transmission and fast GABAergic transmission were routinely blocked with selective antagonists, as were action potentials blocked with TTX.

We observed that the superfusion of BDNF $(20 \mathrm{ng} / \mathrm{ml})$ triggered a rapid inhibition of $\alpha 7 \mathrm{nAChR}$-mediated currents that reached a plateau within $<45 \mathrm{~min}$. The basal amplitudes of nicotinic responses, measured $60 \mathrm{~min}$ after initiating the superfusion of BDNF ( $20 \mathrm{ng} / \mathrm{ml})$, were reduced in 24 of 32 cells tested by $31.6 \pm 6.6 \%(n=24, p<0.001)$ (Fig. $2 A, B)$. A similar inhibition $(38.5 \pm 7.9 \%)$ was observed when patch-clamp experiments were performed in gramicidin-perforated configuration $(n=3$, $p<0.05$ ). The effect of BDNF was dependent on its final concentration in the bath solution. As shown in Figure $2 C$, whereas 1 $\mathrm{ng} / \mathrm{ml}$ BDNF attenuated $\alpha 7 \mathrm{nAChR}$-mediated currents by $17.3 \pm$ $1.7 \%$ in 4 of 5 cells, $100 \mathrm{ng} / \mathrm{ml} \mathrm{BDNF}$ decreased nicotinic responses by $33.5 \pm 4.9 \%$ in 9 of 14 trials, which was not significantly different ( $p>0.05$ ) from the effect produced by $20 \mathrm{ng} / \mathrm{ml}$ in neither terms of magnitude nor the percentage of cells responding. The washout of BDNF (20-100 $\mathrm{ng} / \mathrm{ml})$ was performed in 14 experiments, six of which resulted in the recovery of nicotinic responses to near baseline values $(97.4 \pm 2.0 \%)$ within $45.0 \pm 15.5 \mathrm{~min}$ (Fig. $2 A, B$ ). In the remaining eight cells, the inhibitory effect of BDNF persisted for $1 \mathrm{~h}$ after the washout period was initiated. Noteworthy, the success rate of recovery during washout seemed to be correlated with the concentration of BDNF tested. Although for $20 \mathrm{ng} / \mathrm{ml}$ BDNF currents returned to baseline values in four of six experiments $(\sim 66.7 \%)$, that proportion dropped to two of eight (25\%) when $100 \mathrm{ng} / \mathrm{ml} \mathrm{BDNF}$ was used. This observation, together with the fact that BDNF is a sticky molecule (Lu, 2003), suggests that the failure of $\alpha 7$ nAChR-mediated responses to recover might be attributable to the impossibility of obtaining a complete tissue clearance of the neurotrophin in some experiments. Superfusion of heatinactivated BDNF as a control for unspecific effects of BDNF did 


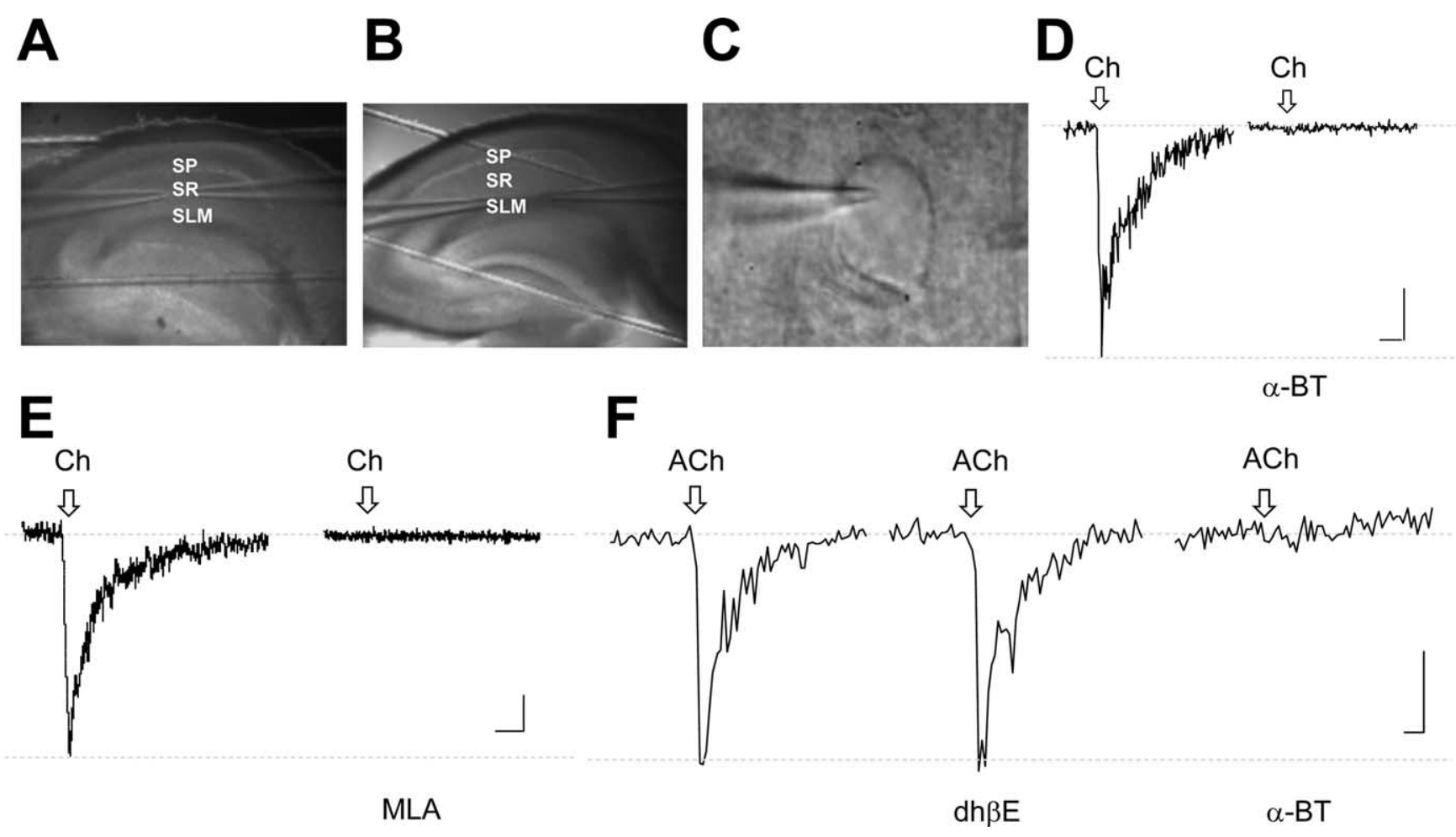

Figure 1. Patch-clamp recordings of $\alpha 7 \mathrm{nAChR}$-mediated currents. $\boldsymbol{A}, \boldsymbol{B}$, Recordings were performed in interneurons located in the stratum radiatum (SR) (A) or at the border of the strata radiatum and lacunosum-moleculare $(\boldsymbol{B})$ of the $(A 1$ region of rat hippocampal slices. $\boldsymbol{C}-\boldsymbol{F}, \alpha 7 \mathrm{nAChR}$-mediated currents were evoked through pressure application of $\mathrm{Ch}$ (10 mM) or Ach (1 mm) locally onto the cell soma $(\boldsymbol{C})$, as indicated by the arrows $(\boldsymbol{D}-\boldsymbol{F})$. The $\alpha 7 \mathrm{nAChR}$ selective antagonists $\alpha$-BT (100 nM) (D) or MLA (10 nM) (E) completely abolished postsynaptic currents induced by $10 \mathrm{~mm}$ Ch. $\boldsymbol{F}$, Currents evoked by $1 \mathrm{~mm} \mathrm{ACh}$ were only considered if the insensitivity to the $\alpha 4 \beta 2 \mathrm{nAChR}$ antagonist $\mathrm{dh} \beta \mathrm{E}(10 \mu \mathrm{m})$ and the full blockade by $\alpha 7 \mathrm{nAChR}$ antagonists were observed at the end of each experiment. Calibration: $\boldsymbol{D}, \boldsymbol{E}, 100 \mathrm{~ms}, 100 \mathrm{pA} ; \boldsymbol{F}, 100 \mathrm{~ms}, 50 \mathrm{pA}$.

not modify the mean amplitude of the recorded currents in any of the cells tested $(n=7)$ (Fig. 3D).

\section{Inhibition of TrkB receptors impairs BDNF-induced suppression of $\alpha 7$ nAChR-mediated currents}

Binding of BDNF to tyrosine kinase TrkB receptors triggers the autophosphorylation of tyrosine residues, which is required for additional phosphorylation steps (Poo, 2001). To evaluate whether the TrkB receptor was involved in the inhibitory action of BDNF on $\alpha 7 \mathrm{nAChRs}$, we studied the effect of this neurotrophin when the tyrosine kinase activity of Trk receptors family was inhibited by addition of the alkaloid K252a (200 nM) (Knusel and Hefti, 1992) to the intracellular solution. In these conditions, $\alpha 7$ nAChR-mediated currents were not modified by $20-100 \mathrm{ng} / \mathrm{ml}$ BDNF in any of the cells tested $(n=5, p<0.05)$ (Fig. 3A).

Previous results from our laboratory suggest that neuromodulation by TrkB tyrosine kinase receptors is tightly dependent on endogenous adenosine acting on $\mathrm{A}_{2 \mathrm{~A}}$ G-protein-coupled receptors (Diogenes et al., 2004). Thus, we evaluated the effect of BDNF (20 ng/ml) when the extracellular adenosine levels were reduced with adenosine deaminase $(1 \mathrm{U} / \mathrm{ml})$ or under pharmacological blockade of adenosine $\mathrm{A}_{2 \mathrm{~A}}$ receptors with SCH 58261 $(100 \mathrm{nM})$. Despite the observation that these drugs did not affect nicotinic responses per se (supplemental Fig. 1, available at www.jneurosci.org as supplemental material), their superfusion in the bath solution prevented the inhibitory effects of BDNF in all cells tested $(n=5-6, p<0.05)$ (Fig. $3 B, D)$.

Taking into account that adenosine $\mathrm{A}_{2 \mathrm{~A}}$ receptors are usually coupled to the cAMP-protein kinase A (PKA) signal transduction system and that PKA might play a role in the crosstalk between $\mathrm{A}_{2 \mathrm{~A}}$ and TrkB receptors in the hippocampus (Diogenes et al., 2004), we further investigated whether the direct inhibition of PKA with H-89 would also restrain the effect of BDNF on $\alpha 7$ nAChRs. In fact, as Figure 3, $C$ and $D$, shows, the intracellular loading of $\mathrm{H}-89(0.1-1 \mu \mathrm{M})$ prevented $(p<0.05)$ the action of BDNF (20 ng/ml) in the majority of the cells tested (four of five) and in one cell attenuated it, corroborating previous evidences that cAMP-dependent processes might regulate the rapid effects of this neurotrophin (Diogenes et al., 2004; Ji et al., 2005).

Together, the data depicted above indicate that the inhibition of $\alpha 7 \mathrm{nAChR}$ function by BDNF requires postsynaptic TrkB receptors with preserved tyrosine kinase activity and agree with previous evidences (Diogenes et al., 2004; Mojsilovic-Petrovic et al., 2006) that the antagonism of adenosine $A_{2 A}$ receptors inhibits activation of TrkB and/or its downstream signaling, even when cells are provided with enough extracellular BDNF to tonically activate its receptor.

\section{BDNF-induced depression of $\alpha 7 \mathrm{nAChR}$ function does not involve Src-family tyrosine kinases}

The activity of Src-family tyrosine kinases (SFKs) has been indicated as one of the mechanisms that can lead to the activation of Trk receptors by adenosine (Lee and Chao, 2001) and to the regulation of $\alpha 7 \mathrm{nAChR}$-mediated currents on hippocampal interneurons (Charpantier et al., 2005). Moreover, a role for Srcfamily kinases in Trk receptor signaling has also been suggested (Iwasaki et al., 1998). Thus, we investigated whether SFKs might participate in the inhibitory effect of BDNF on $\alpha 7$ nAChRs. As Figure 4 shows, when a broad-spectrum inhibitor of SFKs, 100 nм PP2 (Berghuis et al., 2005), was loaded intracellularly, BDNF $(20 \mathrm{ng} / \mathrm{ml})$ still significantly $(p<0.05)$ depressed $\alpha 7 \mathrm{nAChR}$ responses in four of six of cells tested by $49.5 \pm 10.2 \%$, excluding 

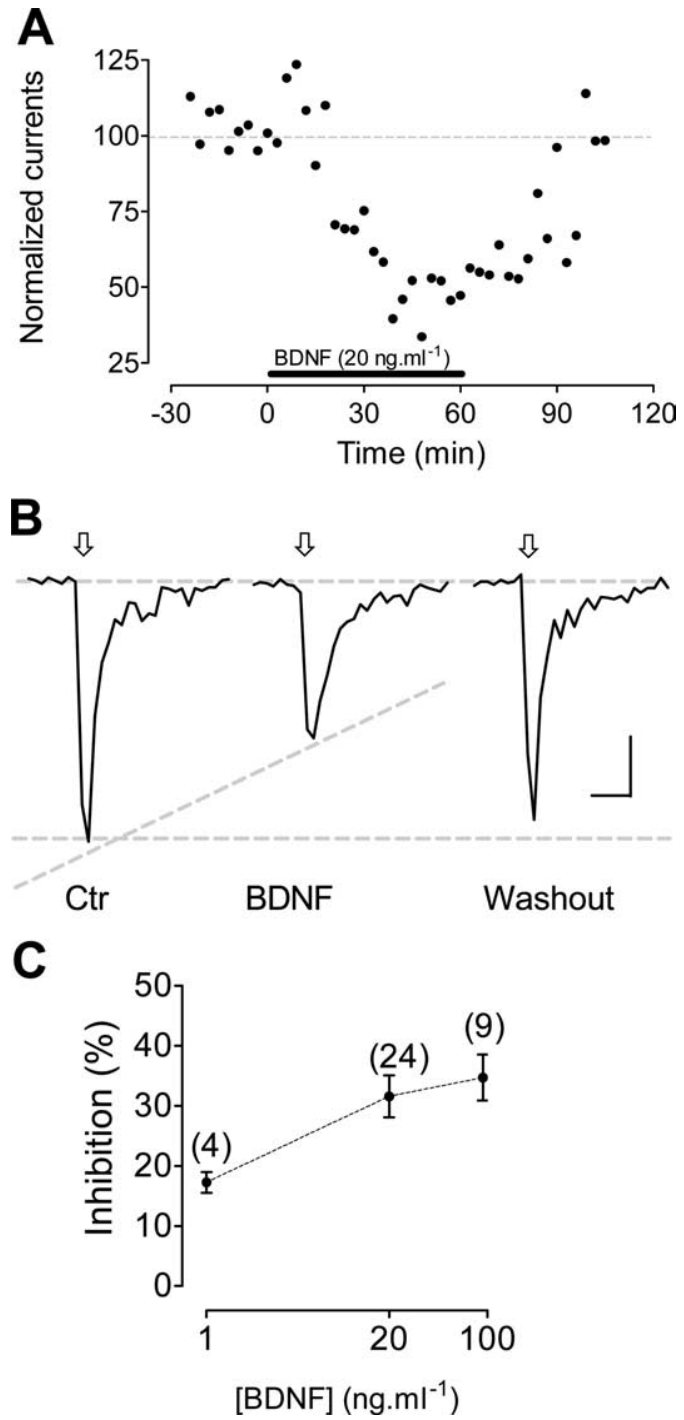

Figure 2. BDNF inhibits $\alpha 7 \mathrm{nAChR}$-mediated currents in CA1 hippocampal interneurons. $\boldsymbol{A}$, Time course of a typical experiment showing normalized peak amplitudes of $\alpha 7 \mathrm{nAChR}$ mediated currents recorded in the absence of drugs, during the superfusion of $20 \mathrm{ng} / \mathrm{ml} \mathrm{BDNF}$ (horizontal black bar) and after a prolonged washout period, as indicated. Sample currents obtained from the same interneuron are shown in $\boldsymbol{B}$. Arrows indicate brief $(30 \mathrm{~ms})$ applications of $\mathrm{Ch}(10 \mathrm{~mm})$ to the soma of interneurons. Calibration: $100 \mathrm{~ms}, 100 \mathrm{pA}$. C, Concentrationdependent inhibition of $\alpha 7 \mathrm{nAChR}$-mediated responses by BDNF (1-100 ng/ml). Each point represents the percentage of inhibition achieved $60 \mathrm{~min}$ after initiating BDNF treatment. The number of experiments is shown in parentheses. Error bars represent SEM.

a putative role of this family of kinases on BDNF-induced inhibition of nicotinic responses.

\section{BDNF action on $\alpha 7 \mathrm{nAChRs}$ process requires the PLC $\gamma / \mathrm{PKC}$} pathway and $\mathrm{Ca}^{2+}$ ions

The autophosphorylation of TrkB receptor tyrosine residues after BDNF binding promotes an interaction with PLC $\gamma$, which can trigger the formation of inositol 1,4,5trisphosphate and diacylglycerol (DAG), an activator of PKC (Widmer et al., 1992, 1993; Zirrgiebel et al., 1995). The activation of this enzymatic system is important in the control of short- and long-term brain functions (ion channel regulation, receptor modulation, neurotransmitter release, synaptic potentiation/depression, neuronal survival) that are related to diverse brain pathologies. This led us to investigate whether the PLC $\gamma /$ PKC pathway was involved in BDNF-induced inhibition of $\alpha 7 \mathrm{nAChR}$. Remarkably, when we included a broadspectrum inhibitor of PLC, U73122 (5 $\mu \mathrm{M}$ ) (Tanaka et al., 1997), in the intracellular solution, BDNF failed to affect $\alpha 7$ nAChR-mediated currents in all cells tested $(n=8)(p<0.05$ compared with the effect of BDNF alone) (Fig. $5 A, F)$. Dialysis of a general inhibitor of PKC isoforms, GF 109203X (2 $\mu \mathrm{M})$, through the patch pipette also completely occluded the effect of BDNF (20 ng/ml) on $\alpha 7 \mathrm{nAChR}$ function $(n=8, p<0.05)$ (Fig. $5 B, F$ ). The PKC family comprises at least 10 isoenzymes, which can be divided into three subfamilies on the basis of their second-messenger requirements (Jaken and Parker, 2000). Conventional PKCs contain the isoforms $\alpha, \beta \mathrm{I}, \beta \mathrm{II}$, and $\gamma$, which require $\mathrm{Ca}^{2+}, \mathrm{DAG}$, and a phospholipid for activation. Novel PKCs include the $\delta, \varepsilon, \eta$, and $\theta$ isoforms and require DAG, but do not require $\mathrm{Ca}^{2+}$ for activation. Conversely, atypical PKCs, which include $\zeta$ and $\iota / \lambda$ isoforms, require neither $\mathrm{Ca}^{2+}$ nor diacylglycerol for activation. Thus, we next evaluated whether the inhibitory actions of BDNF on $\alpha 7$ $\mathrm{nAChR}$ function required calcium signals to occur, in an attempt to investigate which PKC subfamily participated in that mechanism. We found that, despite that BDNF was still able to inhibit $\alpha 7$ nAChR-mediated currents when the fast $\mathrm{Ca}^{2+}$ chelator BAPTA $(10 \mathrm{~mm})$ was loaded intracellularly $(43.0 \pm 9.9 \%$ inhibition, $n=4$ of 7 cells, $p>0.05$ ) (Fig. 5C,F), the neurotrophin did not significantly $(p>0.05)$ modify $\alpha 7 \mathrm{nAChR}$ response in any of the cells tested $(n=4)$ when the intracellular dialysis of BAPTA $(10 \mathrm{~mm})$ was conjugated with the simultaneous removal of extracellular calcium ions (Fig. $5 D, F$ ). Together, these data suggested, therefore, the involvement of a typical isoform of PKC (i.e., with a calcium-binding domain) in BDNF-induced inhibition of $\alpha 7 \mathrm{nAChRs}$. Notably, because intracellular calcium chelation per se did not prevent the effect of BDNF, it is likely that $\alpha 7 \mathrm{nAChRs}$ might supply themselves $\mathrm{Ca}^{2+}$ signals that activate PKC and ultimately lead to the regulation of their function. In a set of experiments, we activated PKC directly through superfusion of PDD ( $1 \mu \mathrm{M})$ and observed that, in such conditions, $\alpha 7 \mathrm{nAChR}$ responses were decreased by $32.2 \pm 7.3$ in four of six cells, mimicking the isolated effect of BDNF (Fig. $5 E, F$ ).

\section{The attenuation of $\alpha 7 \mathrm{nAChRs}$ function by BDNF involves the actin cytoskeleton}

The trafficking of neuronal $\alpha 7 \mathrm{nAChRs}$ into/from the plasma membrane depends on cytoskeleton proteins, such as actin (Shoop et al., 2000; Chang and Fischbach, 2006). Recent evidences suggesting that BDNF preserves a significant influence on the actin cytoskeleton in the mature nervous system (Rex et al., 2007) prompted us to investigate whether the attenuation of $\alpha 7 \mathrm{nAChR}$ function by BDNF could be regulated at that level. To test such possibility, we examined the efficacy of BDNF in modulating nicotinic responses of interneurons previously loaded with the actin depolymerizing agent cytochalasin D (5 $\mu \mathrm{M})$ (Cooper, 1987). Notably, BDNF (20 ng/ml) failed to significantly modify $\alpha 7 \mathrm{nAChR}$-mediated currents in all cells tested under those conditions $(n=4, p>0.05)$ (Fig. 6). These results suggest that the acute actions of BDNF on $\alpha 7$ nAChRs require the intact actin cytoskeleton to undergo structural alterations that ultimately affect the stability, and thus the function, of $\alpha 7 \mathrm{nAChRs}$ in the cell membrane. 

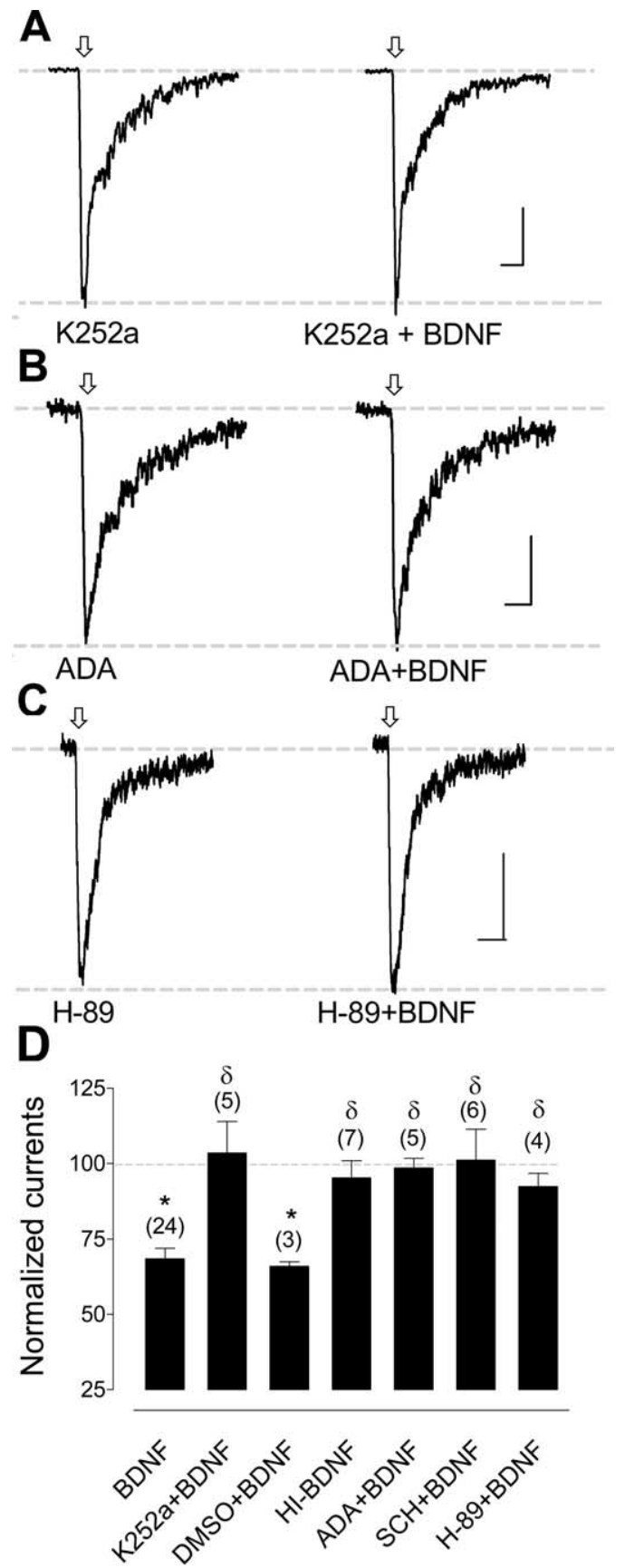

Figure 3. BDNF-induced depression of $\alpha 7 \mathrm{nAChR}$-mediated currents involves a Trk-type receptor. $A$, Illustrative currents showing that postsynaptic loading of the tyrosine kinase receptor inhibitor K252a ( $200 \mathrm{~nm}$ ) prevented the inhibitory action of BDNF. B, Bath application of ADA $(1 \mathrm{U} / \mathrm{ml})$ also prevented the effect of BDNF on $\alpha 7 \mathrm{nAChRs}$. C, Blockade of PKA by intracellular dialysis of H-89 (1 $\mu \mathrm{m})$ impaired BDNF (20 ng/ml) ability to depress $\alpha 7 \mathrm{nAChR}$-mediated currents. D, Summary of data, as indicated. BDNF (20 ng/ml), HI-BDNF (20 ng/ml BDNF boiled for $30 \mathrm{~min}), \mathrm{ADA}(1 \mathrm{U} / \mathrm{ml})$, or adenosine $\mathrm{A}_{2 \mathrm{~A}}$ receptor antagonist SCH 58261 (100 nM) were applied in the superfusion solution for at least 30 min before BDNF. K252a ( $200 \mathrm{nM})$, DMSO (0.1\% v/v), or H-89 $(0.1-1 \mu \mathrm{M})$ were included in the intracellular solution. Mean effects were quantified $60 \mathrm{~min}$ after BDNF application for all data. The number of experiments is shown in parentheses. Error bars represent SEM. ${ }^{*} p<0.001$ compared with mean values before BDNF (two-tailed Student's $t$ test). ${ }^{\delta_{p}}<$ 0.05 compared with BDNF alone (one-way ANOVA). Calibration: $100 \mathrm{~ms}, 100 \mathrm{pA}$.

\section{Discussion}

The results outlined here identify for the first time a neurotrophin gene family member as an acute modulator of nAChRs activity in the CNS. In our conditions, BDNF significantly attenuated $\alpha 7 \mathrm{nAChR}$-mediated currents in the vast majority of

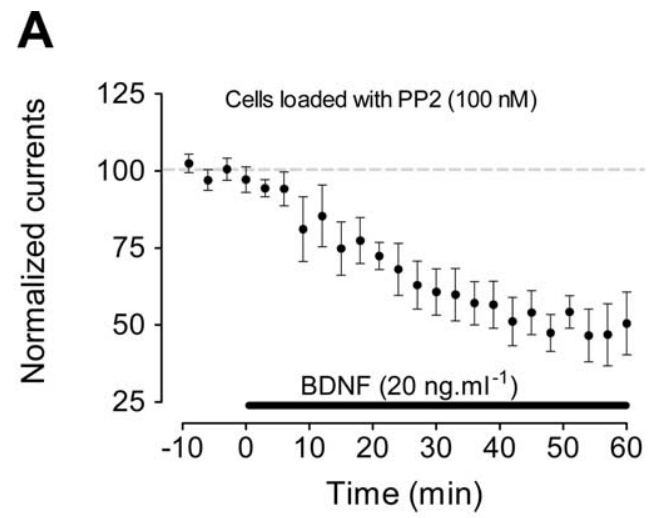

B

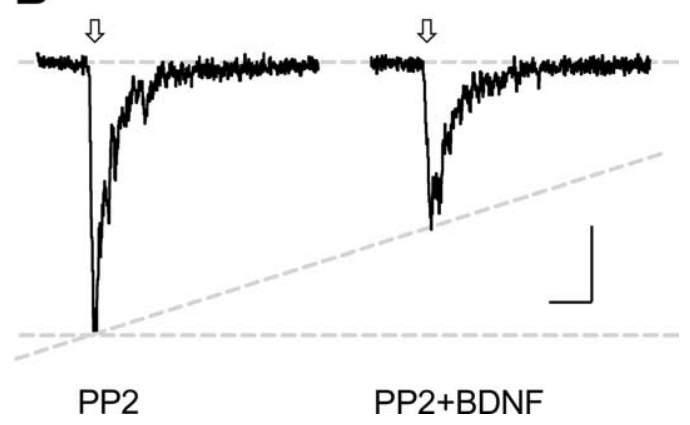

Figure 4. The inhibitory action of BDNF on $\alpha 7 \mathrm{nAChR}$-mediated responses does not involve the activity of Src-kinases family. $A$, Time course plots showing the effect of $20 \mathrm{ng} / \mathrm{ml}$ BDNF (horizontal black bar) on Ch-evoked currents recorded with an intracellular solution containing a Src-kinases-family inhibitor, PP2 (100 nM). Error bars represent SEM. B, Illustrative currents. Arrows, Brief ( $30 \mathrm{~ms})$ application of $\mathrm{Ch}(10 \mathrm{~mm})$ to the soma of the interneuron. Calibration: 100 $\mathrm{ms}, 100 \mathrm{pA}$.

hippocampal interneurons tested. The absence of response to BDNF verified in less than one-fourth of the cells might be attributable to differences in density/distribution of TrkB receptors, to downstream signaling pathways, or, less likely, to a difficult penetration of BDNF is some slices. The effect of BDNF on postsynaptic $\alpha 7 \mathrm{nAChRs}$ was dose dependent, reversible, and mediated through the activation of tyrosine kinase TrkB receptors. Additionally, we showed that constitutively released adenosine, acting on $\mathrm{A}_{2 \mathrm{~A}}$ receptors, was required to gate the action of $\mathrm{BDNF}$ in our system. Although corroborating several evidences on the tight relationship between tyrosine kinase TrkB and adenosine $A_{2 A}$ receptors, this set of results contrasts with BDNF-induced modulation of synaptic inputs to pyramidal cells, which require exogenous activation of $\mathrm{A}_{2 \mathrm{~A}}$ receptors (Diogenes et al., 2004). It is thus possible that either adenosine levels are greater in the vicinity of interneurons or, alternatively, that interneurons might exhibit an increased sensitivity for the basal levels of adenosine. In fact, both possibilities are consistent with several reports showing that extracellular adenosine levels affect interneurons in a more powerful manner than pyramidal cells (Congar et al., 1995; Fortunato et al., 1996).

We further demonstrated the involvement of the PLC $\gamma /$ PKC signaling cascade downstream of TrkB receptor activation in the attenuation of $\alpha 7 \mathrm{nAChR}$ function. Interestingly, previous studies suggested that PKC restrained paired-pulse potentiation of $\alpha 7 \mathrm{nAChRs}$ in rat hippocampal interneurons (Klein and Yakel, 2005) and accelerated agonist-induced desensitization of $\mathrm{nAChR}$ in sympathetic ganglion neurons (Downing and Role, 1987). Consistent with those evidences, 
the direct activation of PKC by phorbol esters caused a pronounced inhibition of $\alpha 7 \mathrm{nAChR}$-mediated currents in our experimental conditions. Future work is expected to clarify whether PKC plays an instructive or permissive role in this mechanism. Although it was outside of the scope of the present study to distinguish between those two possibilities, it would be tempting to speculate about the involvement of PKC in a hypothetical phosphorylation of $\alpha 7 \mathrm{nAChRs,} \mathrm{known}$ to be negatively coupled to the regulation of nicotinic responses (Charpantier et al., 2005). However, predicted consensus sequences for PKC phosphorylation are absent from the intracellular domains of $\alpha 7$ subunits, and, therefore, neuronal $\alpha 7$ nAChRs do not seem to constitute a potential substrate for direct PKC phosphorylation (Seguela et al., 1993; Moss et al., 1996). Nevertheless, it is possible that the acute inhibitory effect of BDNF on $\alpha 7$ nAChR function might involve phosphorylation/dephosphorylation of intermediate proteins that regulate trafficking, clustering, and/or lateral diffusion of the receptors.

Our results further suggest that TrkB receptor activation leads to functional changes of the $\alpha 7 \mathrm{nAChR}$ that depend on $\mathrm{Ca}^{2+}$ influx. In fact, the complete prevention of BDNF action on $\alpha 7 \mathrm{nAChR}$ responses was only achieved when intracellular $\mathrm{Ca}^{2+}$ chelation was combined with the replacement of external $\mathrm{Ca}^{2+}$ with $\mathrm{Ba}^{2+}$ ions. Because in our experimental conditions $\mathrm{Ca}^{2+}$ influx mostly occurs through $\alpha 7 \mathrm{nAChRs}$, the action of BDNF here reported might play an important role on the regulation of cations influx and act to restrain excessive cell depolarization and avoid calcium-induced toxicity.

Recently, it was reported that longterm treatment ( $16-72 \mathrm{~h}$ ) with BDNF upregulates intracellular and surface pools of $\alpha 7 \mathrm{nAChRs}$ in subpopulations of hippocampal interneurons that mainly innervate pyramidal cells (Massey et al., 2006). However, it remains to be investigated which signaling cascades are involved in that long-term effect and whether this effect is correlated with functional modifications of nicotinic responses. Knowledge about these issues is expected to clarify whether a common pathway downstream of TrkB receptor activation is responsible for the acute and chronic modifications of $\alpha 7 \mathrm{nAChR}$ function induced by BDNF. A biphasic response induced by $\mathrm{BDNF} / \mathrm{TrkB}$ receptor activation would be in line with the
A

B
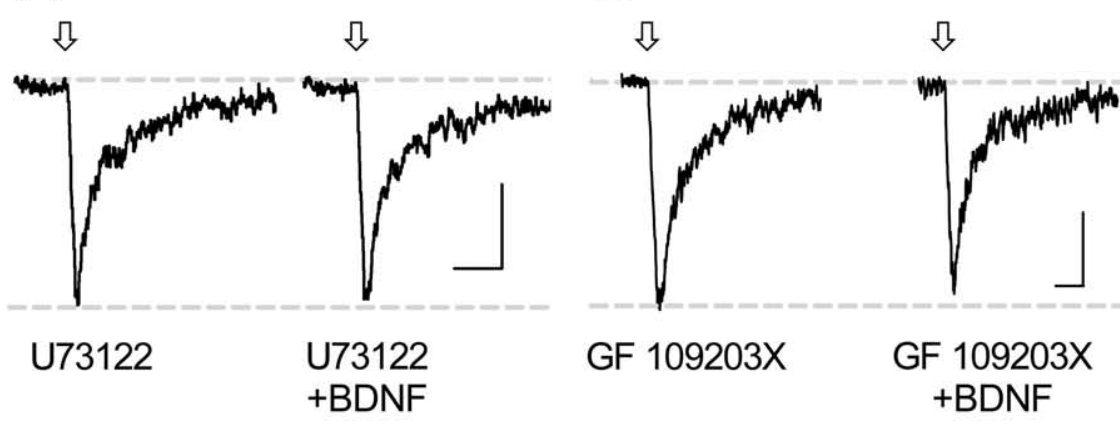

C

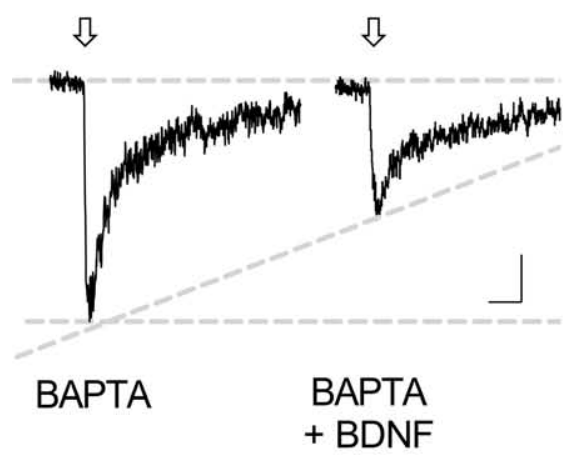

ת

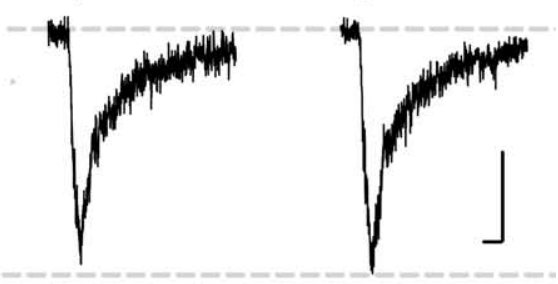

BAPTA

BAPTA

$+0 \mathrm{mM}\left[\mathrm{Ca}^{2+}\right]_{0}+0 \mathrm{mM}\left[\mathrm{Ca}^{2+}\right]_{0}$

+ BDNF
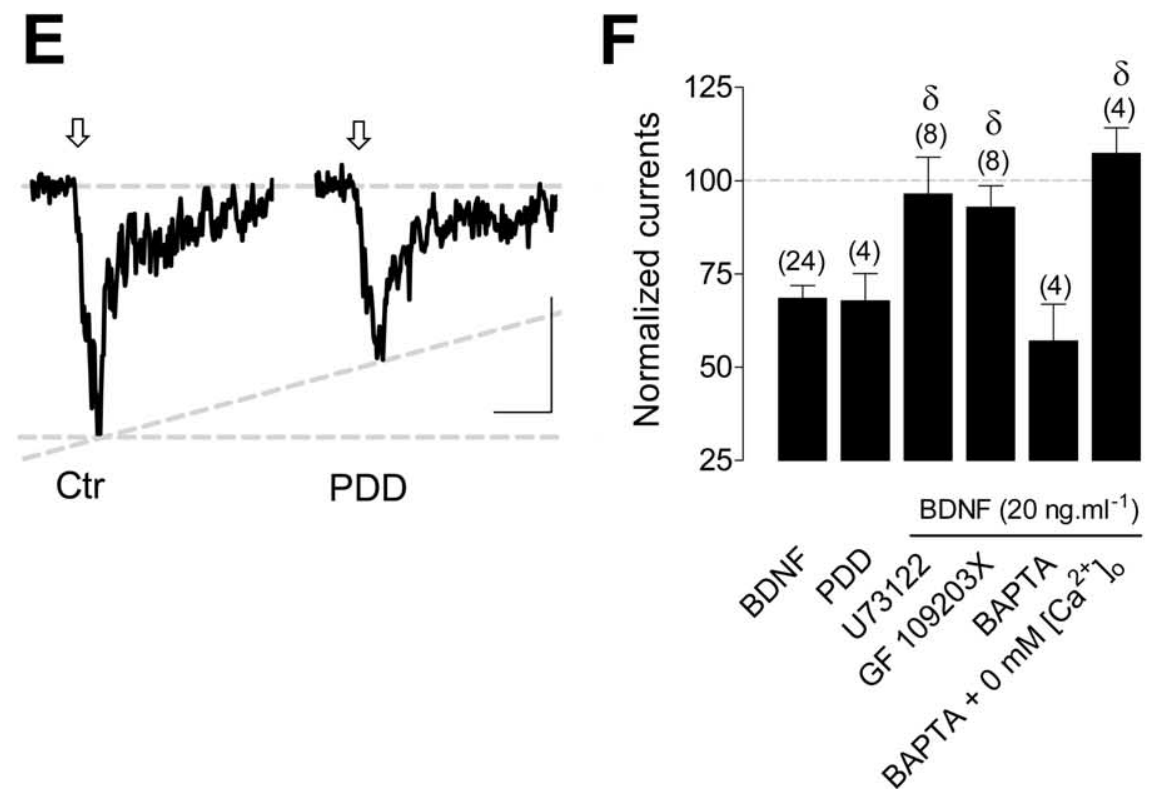

Figure 5. Signaling pathways involved in BDNF-induced inhibition of $\alpha 7 \mathrm{nAChR}$-mediated currents. $\boldsymbol{A}-\boldsymbol{D}$, Each panel displays two illustrative currents obtained immediately before and $60 \mathrm{~min}$ after adding BDNF to the bath solution ( $20 \mathrm{ng} / \mathrm{ml}$ ). BDNF failed to modify the amplitude of nicotinic responses when the PLC blocker U73122 $(5 \mu \mathrm{M})(A)$ or the PKC inhibitor GF $109203 X$ $(2 \mu \mathrm{M})(B)$ were dialyzed through the patch pipette. The intracellular chelation of calcium with the fast $\mathrm{Ca}^{2+}$ chelator BAPTA did not affect the action of BDNF on $\alpha 7 \mathrm{nAChR}$-mediated responses ( $\left(\boldsymbol{)}\right.$, unless extracellular $\mathrm{Ca}^{2+}$ was simultaneously removed (D), a condition in which the depression caused by BDNF was totally suppressed. $\boldsymbol{E}$, Treatment with PDD $(1 \mu \mathrm{M})$, a PKC activator, mimicked the inhibitory effect of BDNF on $\alpha 7 \mathrm{nAChR}$-mediated responses. $\boldsymbol{F}$, Histogram showing the mean effects of PDD and BDNF $(20 \mathrm{ng} / \mathrm{ml})$ on the peak amplitudes of $\alpha 7 \mathrm{nAChR}$-mediated currents after the pharmacological manipulations indicated. BDNF $(20 \mathrm{ng} / \mathrm{ml})$ and PDD were added to the bathing solution. U73122 $(5 \mu \mathrm{M})$ and GF $109203 \mathrm{X}(2 \mu \mathrm{M})$ were included in the intracellular solution and loaded directly into the postsynaptic cell. In the experiments in which $\left[\mathrm{Ca}^{2+}\right]_{0}$ was $0 \mathrm{~mm}, \mathrm{CaCl}_{2}(2 \mathrm{~mm})$ was substituted by $\mathrm{BaCl}_{2}(2 \mathrm{~mm})$ in the extracellular solution. Mean effects were quantified $60 \mathrm{~min}$ after BDNF or PDD application for all data. The number of experiments is shown in parentheses. Error bars represent SEM. Arrows indicate brief $(30 \mathrm{~ms})$ application of $\mathrm{Ch}(10 \mathrm{~mm})$ to the soma of interneurons. ${ }^{\delta} p<0.05$ compared with the effect of BDNF alone (one-way ANOVA). Calibration: $100 \mathrm{~ms}, 100 \mathrm{pA}$. 


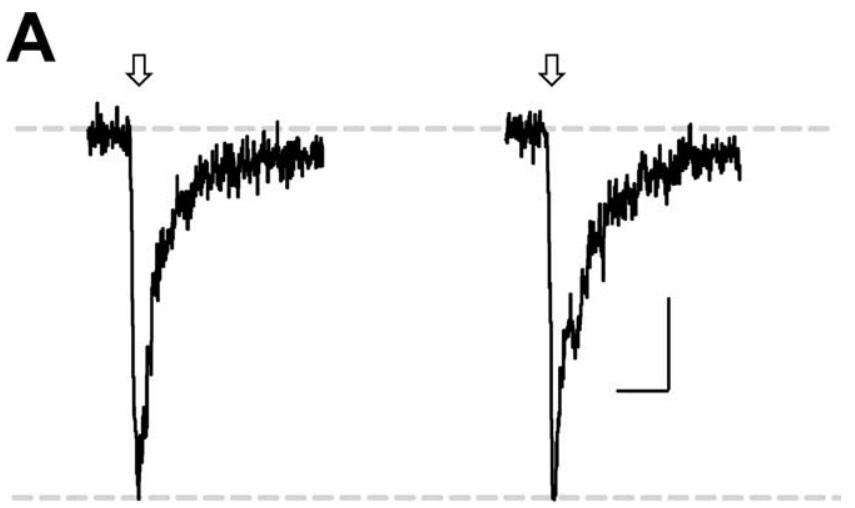

\section{Cyt D $\quad$ Cyt D+BDNF}

B

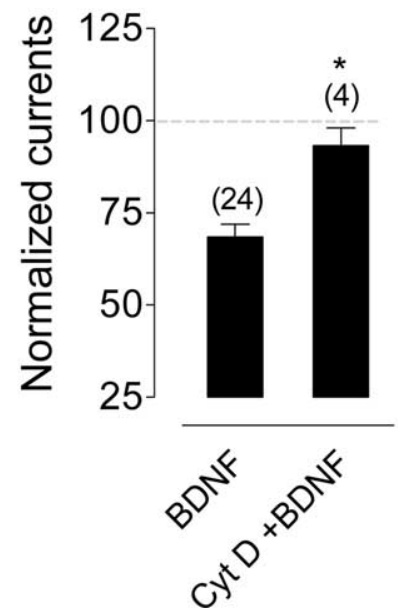

Figure 6. Disruption of the actin cytoskeleton prevents the acute inhibitory action of BDNF on $\alpha 7$ nAChRs. $\boldsymbol{A}, \alpha 7$ nAChR-mediated responses evoked by local pressure application of choline $(10 \mathrm{~mm})$ in interneurons loaded with the F-actin filament disrupter $C y t D(5 \mu \mathrm{m})$, before and during the administration of BDNF $(20 \mathrm{ng} / \mathrm{ml})$. $B$, Bar plot of mean currents amplitude for the experiments described in A. BDNF $(20 \mathrm{ng} / \mathrm{ml}$ ) was added to the bathing solution. Cytochalasin D was included in the intracellular solution and allowed to act directly inside the postsynaptic cell. Mean effects were quantified 60 min after starting the superfusion of BDNF. The number of experiments is shown in parentheses. Error bars represent SEM. Arrows indicate brief ( $30 \mathrm{~ms}$ ) application of $\mathrm{Ch}(10 \mathrm{~mm})$ to the soma of interneurons. ${ }^{*} p<0.05$ compared with the effect of BDNF alone (two-tailed Student's $t$ test). Calibration: $100 \mathrm{~ms}, 100 \mathrm{pA}$.

action of neuregulin-1/ErbB4 receptor signaling on nicotinic responses, in the sense that this system also acutely depresses $\alpha 7 \mathrm{nAChR}$ function and chronically enhances $\alpha 7 \mathrm{nAChR}$ number and function in the plasma membrane (Liu et al., 2001; Chang and Fischbach, 2006). Future studies will allow determining how different tyrosine kinase receptors coordinate the regulation of $\alpha 7 \mathrm{nAChRs}$ and whether they interact for that purpose. Noteworthy, the actin cytoskeleton appears to play a pivotal role on both inhibitory actions of ErbB4 and TrkB receptors on $\alpha 7 \mathrm{nAChR}$ function.

In contrast to glutamate NMDA receptors, neuronal $\alpha 7$ $\mathrm{nAChRs}$ remain active at highly negative potentials and might supply $\mathrm{Ca}^{2+}$ signals even in these conditions. Hence, the action of BDNF now described might contribute to set the background responsiveness of $\alpha 7 \mathrm{nAChRs}$ and should be taken into account when considering their participation in the whole neuronal network activity. It has been shown that postsynaptic $\alpha 7$ nAChR-mediated inputs to GABAergic interneurons regulate inhibition within the hippocampal network (Jones and Yakel, 1997; Alkondon et al., 1999). In this context, because BDNF does not modify acetylcholine-induced currents in glutamatergic neurons (Levine et al., 1998), it is plausible that the dramatic increase in BDNF secretion induced by intense stimulation of hippocampal excitatory circuits (Gartner and Staiger, 2002) might temporarily alleviate $\alpha 7 \mathrm{nAChR}$ mediated inputs to interneurons that tend to oppose shortand long-term potentiation in pyramidal cells (Ji et al., 2001). Given the key role of TrkB-PLC $\gamma$ docking site in synaptic plasticity (Gruart et al., 2007) and the reversibility of BDNF action on $\alpha 7 \mathrm{nAChRs}$, the present data might also configure a mechanism involved in the adaptation to local changes in neuronal activity that occur in the hippocampus during learning and memory formation. Our results widen the fundamental mechanisms by which BDNF influences synaptic transmission and synaptic plasticity in the CNS. Because alterations on BDNF levels and disruption of $\alpha 7 \mathrm{nAChR}$ function in the hippocampus have been involved in cognitive deficits and dementia, it is expected that the link now described constitutes a target for novel pharmacological approaches for the treatment of those disorders.

\section{References}

Alkondon M, Pereira EFR, Barbosa CTF, Albuquerque EX (1997) Neuronal nicotinic acetylcholine receptor activation modulates $\gamma$-aminobutyric acid release from CA1 neurons of rat hippocampal slices. J Pharmacol Exp Ther 283:1396-1411.

Alkondon M, Pereira EFR, Eisenberg HM, Albuquerque EX (1999) Choline and selective antagonists identify two subtypes of nicotinic acetylcholine receptors that modulate GABA release from CA1 interneurons in rat hippocampal slices. J Neurosci 19:2693-2705.

Anderson WW, Collingridge GL (2007) Capabilities of the WinLTP data acquisition program extending beyond basic LTP experimental functions. J Neurosci Methods 162:346-356.

Berghuis P, Dobszay MB, Wang X, Spano S, Ledda F, Sousa KM, Schulte G, Ernfors P, Mackie K, Paratcha G, Hurd YL, Harkany T (2005) Endocannabinoids regulate interneuron migration and morphogenesis by transactivating the TrkB receptor. Proc Natl Acad Sci USA 102:19115-19120.

Bertrand D, Galzi JL, Devillers-Thiery A, Bertrand S, Changeux JP (1993) Mutations at two distinct sites within the channel domain M2 alter calcium permeability of neuronal $\alpha 7$ nicotinic receptor. Proc Natl Acad Sci USA 90:6971-6975.

Chang Q, Fischbach GD (2006) An acute effect of neuregulin $1 \beta$ to suppress $\alpha 7$-containing nicotinic acetylcholine receptors in hippocampal interneurons. J Neurosci 26:11295-11303.

Charpantier E, Wiesner A, Huh KH, Ogier R, Hoda JC, Allaman G, Raggenbass M, Feuerbach D, Bertrand D, Fuhrer C (2005) $\alpha 7$ neuronal nicotinic acetylcholine receptors are negatively regulated by tyrosine phosphorylation and Src-family kinases. J Neurosci 25:9836-9849.

Congar P, Khazipov R, Ben-Ari Y (1995) Direct demonstration of functional disconnection by anoxia of inhibitory interneurons from excitatory inputs in rat hippocampus. J Neurophysiol 73:421-426.

Cooper JA (1987) Effects of cytochalasin and phalloidin on actin. J Cell Biol 105:1473-1478.

Diogenes MJ, Fernandes CC, Sebastiao AM, Ribeiro JA (2004) Activation of adenosine $A_{2 A}$ receptor facilitates brain-derived neurotrophic factor modulation of synaptic transmission in hippocampal slices. J Neurosci 24:2905-2913.

Downing JE, Role LW (1987) Activators of protein kinase C enhance acetylcholine receptor desensitization in sympathetic ganglion neurons. Proc Natl Acad Sci USA 84:7739-7743.

Elmslie FV, Rees M, Williamson MP, Kerr M, Kjeldsen MJ, Pang KA, Sundqvist A, Friis ML, Chadwick D, Richens A, Covanis A, Santos M, Arzimanoglou A, Panayiotopoulos CP, Curtis D, Whitehouse WP, Gardiner RM (1997) Genetic mapping of a major susceptibility locus for 
juvenile myoclonic epilepsy on chromosome 15q. Hum Mol Genet 6:1329-1334.

Figurov A, Pozzo-Miller LD, Olafsson P, Wang T, Lu B (1996) Regulation of synaptic responses to high-frequency stimulation and LTP by neurotrophins in the hippocampus. Nature 381:706-709.

Fortunato C, Debanne D, Scanziani M, Gähwiler BH, Thompson SM (1996) Functional characterization and modulation of feedback inhibitory circuits in area CA3 of rat hippocampal slice cultures. Eur J Neurosci 8:1758-1768.

Freedman R, Adler LE, Bickford P, Byerley W, Coon H, Cullum CM, Griffith JM, Harris JG, Leonard S, Miller C (1994) Schizophrenia and nicotinic receptors. Harv Rev Psychiatry 2:179-192.

Gartner A, Staiger V (2002) Neurotrophin secretion from hippocampal neurons evoked by long-term-potentiation-inducing electrical stimulation patterns. Proc Natl Acad Sci USA 99:6386-6391.

Gray R, Rajan AS, Radcliffe KA, Yakehiro M, Dani JA (1996) Hippocampal synaptic transmission enhanced by low concentrations of nicotine. Nature 383:713-716.

Gruart A, Sciarretta C, Valenzuela-Harrington M, Delgado-Garcia JM, Minichiello L (2007) Mutation at the TrkB PLC $\gamma$-docking site affects hippocampal LTP and associative learning in conscious mice. Learn Mem 14:54-62.

Guan ZZ, Zhang X, Ravid R, Nordberg A (2000) Decreased protein levels of nicotinic receptor subunits in the hippocampus and temporal cortex of patients with Alzheimer's disease. J Neurochem 74:237-243.

Iwasaki Y, Gay B, Wada K, Koizumi S (1998) Association of the Src family tyrosine kinase Fyn with TrkB. J Neurochem 71:106-111.

Jaken S, Parker PJ (2000) Protein kinase C binding partners. BioEssays 22:245-254

Ji D, Lape R, Dani JA (2001) Timing and location of nicotinic activity enhances or depresses hippocampal synaptic plasticity. Neuron 31:131-141.

Ji Y, Pang PT, Feng L, Lu B (2005) Cyclic AMP controls BDNF-induced TrkB phosphorylation and dendritic spine formation in mature hippocampal neurons. Nat Neurosci 8:164-172.

Jones S, Yakel JL (1997) Functional nicotinic ACh receptors on interneurones in the rat hippocampus. J Physiol (Lond) 504:603-610.

Kang H, Schuman EM (1995) Long-lasting neurotrophin-induced enhancement of synaptic transmission in the adult hippocampus. Science 267:1658-1662

Kawai H, Zago W, Berg DK (2002) Nicotinic $\alpha 7$ receptor clusters on hippocampal GABAergic neurons: regulation by synaptic activity and neurotrophins. J Neurosci 22:7903-7912.

Klein RC, Yakel JL (2005) Paired-pulse potentiation of alpha7-containing nAChRs in rat hippocampal CAl stratum radiatum interneurones. J Physiol (Lond) 568:881-889.

Knusel B, Hefti F (1992) K-252 compounds: modulator of neurotrophin signal transduction. J Neurochem 59:1987-1996.

Korte M, Carroll P, Wolf E, Brems G, Thoenen H, Bonhoeffer T (1995) Hippocampal long-term potentiation is impaired in mice lacking brain-derived neurotrophic factor. Proc Natl Acad Sci USA 92:8856-8860.

Lee FS, Chao MV (2001) Activation of Trk neurotrophin receptors in the absence of neurotrophins. Proc Natl Acad Sci USA 98:3555-3560.

Levine ES, Crozier RA, Black IB, Plummer MR (1998) Brain-derived neurotrophic factor modulates hippocampal synaptic transmission by increasing $N$-methyl-D-aspartic acid receptor activity. Proc Natl Acad Sci USA 95:10235-10239.
Liu Y, Ford B, Mann MA, Fischbach GD (2001) Neuregulins increase $\alpha 7$ nicotinic acetylcholine receptors and enhance excitatory synaptic transmission in GABAergic interneurons of the hippocampus. J Neurosci $21: 5660-5669$

Lu B (2003) BDNF and activity-dependent synaptic modulation. Learn Mem 10:86-98.

Massey KA, Zago WM, Berg DK (2006) BDNF up-regulates $\alpha 7$ nicotinic acetylcholine receptor levels on subpopulations of hippocampal interneurons. Mol Cell Neurosci 33:381-388.

Mojsilovic-Petrovic J, Jeong GB, Crocker A, Arneja A, David S, Russell D, Kalb RG (2006) Protecting motor neurons from toxic insult by antagonism of adenosine $\mathrm{A}_{2 \mathrm{~A}}$ and Trk receptors. J Neurosci 26:9250-9263.

Moss SJ, McDonald BJ, Rudhard Y, Schoepfer R (1996) Phosphorylation of the predicted major intracellular domains of the rat and chick neuronal nicotinic acetylcholine receptor alpha 7 subunit by cAMP-dependent protein kinase. Neuropharmacology 35:1023-1028.

Patterson SL, T Abel, TA Deuel, KC Martin, JC Rose, ER Kandel (1996) Recombinant BDNF rescues deficits in basal synaptic transmission and hippocampal LTP in BDNF knockout mice. Neuron 16:1137-1145.

Poo MM (2001) Neurotrophins as synaptic modulators. Nat Rev Neurosci 2:24-32.

Radcliffe KA, Dani JA (1998) Nicotinic stimulation produces multiple forms of increased glutamatergic synaptic transmission. J Neurosci 18:7075-7083.

Rex CS, Lin CY, Kramár EA, Chen LY, Gall CM, Lynch G (2007) Brainderived neurotrophic factor promotes long-term potentiation-related cytoskeletal changes in adult hippocampus. J Neurosci 27:30173029.

Seguela P, Wadiche J, Dineley-Miller K, Dani JA, Patrick JW (1993) Molecular cloning, functional properties, and distribution of rat brain $\alpha 7$ : a nicotinic cation channel highly permeable to calcium. J Neurosci 13:596-604.

Shoop RD, Yamada N, Berg DK (2000) Cytoskeletal links of neuronal acetylcholine receptors containing $\alpha 7$ subunits. J Neurosci 20:4021-4029.

Tanaka T, Saito H, Matsuki N (1997) Inhibition of $\mathrm{GABA}_{\mathrm{A}}$ synaptic responses by brain-derived neurotrophic factor (BDNF) in rat hippocampus. J Neurosci 17:2959-2966.

Thoenen H, (1991) The changing scene of neurotrophic factors. Trends Neurosci 14:165-170.

Wang HY, Lee DH, D'Andrea MR, Peterson PA, Shank RP, Reitz AB (2000) beta-Amyloid(1-42) binds to alpha7 nicotinic acetylcholine receptor with high affinity. Implications for Alzheimer's disease pathology. J Biol Chem 275:5626-5632.

Widmer HR, Knusel B, Hefti F (1992) Stimulation of phosphatidylinositol hydrolysis by brain-derived neurotrophic factor and neurotrophin- 3 in rat cerebral cortical neurons developing in culture. J Neurochem 59:2113-2124.

Widmer HR, Kaplan DR, Rabin SJ, Beck KD, Hefti F, Knusel B (1993) Rapid phosphorylation of phospholipase $\mathrm{C} 1$ by brain-derived neurotrophic factor and neurotrophin-3 in cultures of embryonic rat cortical neurons. J Neurochem 60:2111-2123.

Zirrgiebel U, Ohga Y, Carter B, Berninger B, Inagaki N, Thoenen H, Lindoholm D (1995) Characterization of TrkB receptor-mediated signaling pathways in rat cerebellar granule neurons: involvement of protein kinase C in neuronal survival. J Neurochem 65:2241-2250. 